formation. And if the people in the Dog Star chose to define four as $\mathbf{I}+\mathbf{I}+\mathbf{I}$, the so-called "necessary truth" would not even be true! Again, we do not " recognize that what we know 'is' cannot at the same time 'not be,'" we define it to be so. To know that anything "is," is indeed to possess real knowledge ; but in order to conclude that therefore it cannot "not be," we require no further knowledge, except as to the meanings of the words employed in the argument. The "law of contradiction " never tells us whether anything "is" or "is not." It only tells us that the terms "is" and "is not" are not applicable to the same thing. This is part of the definition of the terms. If anyone chooses to say a thing both " is " and " is not," there is no law against his doing so, only if he does so he is not talking the Queen's English. Dr. Mivart is wrong in speaking of the "objective absolute validity of the law of contradiction." Its validity is not only not objective at all, but even subjectively it is not absolute, but depends on the arbitrary meanings assigned to its terms. It is exactly on a par with the assertion that at chess one king cannot give check to another.

Trinity College, Cambridge, November 29. EDWARD T. DIXON.

\section{The Koh-i-Nur.}

ABSENCE from home and pressing business since my return have delayed my sending a reply to Prof. Maskelyne's second article upon the above subject (N $\mathrm{NTURE}$, November 5, p. 5). So far as I can discern Prof. Maskelyne's primary object in writing these articles, it is to endeavour to maintain the hypothesis put forward by him many years ago ; and with this object in view he has made a number of statements, from which $I$ have culled not a few that may be ranged under either of two heads -firstly, those which I believe can be shown to be distinctly contrary to the evidence ; and secondly, those which, if not directly contradicted by the evidence, are quite unsupported by it In my first reply I gave samples of these statements which afforded perfectly clear issues, and as these have been unanswered, it is useless to refer to others in detail at present.

Some readers of what has already been written have expressed to me their regret that finality has not been attained by this discussion. For my own part I have a feeling of sincere regret at any additional confusion being introduced into the subject. Some of the statements referred to may, unless a warning be given, be quoted in the future, as others have been in the past, by writers who may not have the means or may no be willing to take the trouble to refer to the original authors.

There are several references in Prof. Maskelyne's last article to authors with whose writings I have considered it to be my business and duty to make inyself familiar. I possess their works, and of one of them I have recently published a detailed commentary, while of another I have a comnentary in course of preparation. Among these authors are Carcia de Orta and Chappuzeau, and Prof. Maskelyne's remark; lead me to conclude that he has not a very intimate acquaintance with their writings and with those of some of their contemporaries. From internal evidence it is practically certain that at the time Garcia wrote his book he had not visited the Mogul's Court, and could not, therefore, have seen his jewels, though, for the sake of argument, Prof. Maskelyne suggests he had. As for the discredited Chappuzeau, whose malicious statements are quoted without their refuta ion. I need only say that Prof. Joret's investigations have cleared Tavernier of the charges of plagiarism, \&c., which were made against him, and they have further disclosed the fact that his own original manuscript documents, from which the "Travels" were prepared, are still extant (see preface to the second volume of my edition of the "Travels").

Now, as to the De Boot mistake, to which Prof. Maskelyne again refers as though it had an important bearing on the subject, it is the case that Mr. King, in a footnote, pointed out the error in De Boot's quoting as from Monardes. The footnote does not occur in Mr. King's account of the diamonds, but elsewhere. When I wrote, I had Prof. Maskelyne's quotation (Edinburgh Reviezw), as from Mr. King, before me, and thus I was for the moment misled as to the extent of Mr. King's knowledge. Seeing, then, that it was Prof. Maskelyne's misquotation which misled me, his not having accepted my invitation to explain, coupled with his crowing over me for having been misled (by his own words), is one of the most extraordinary features in this controversy. Two years ago I annotated my original paper with the remark that Mr. King had noticed the mistake of De Boot about Monardes, but it was then too late to correct the press.

The confusion which has most unfortunately been introduced into this subject by authors has now, it is to be fervently hoped, culminated in the publication by Prof. Maskelyne of a figure of a huge mounted jewel, which, going much further than his previous reference to it might have led one to expect, he labels "The Mogul." What the authority may be for this sketch, we are not clearly informed; all, apparently, that can be said for it is that "it speaks for itself" I cannot understand how Sir John Malcolm can be responsible for it, at least as it is labelled, because I know what he has published about the Shah's jewels, especially the Darya- $i$-Nur and its companion the Taj-e-mah. Kerr-Purter, Eastwick, and others who have described the Shah's jewels, make no inention of the existence of any such stone as this figure represents.

"It speaks for itself"; and I must venture by two alternatives to hazard an interpretation of what it says. Firstly, the amorphous-looking mass may be intended to represent some uncut stone, possibly a ruby; but why should it be the Mogul's diamond, which is known to have been cut? Secondly, it seems to be more probable that the figure may have been taken from a native sketch which originally professed to represent, but greatly exaggerated the size, and omitted the facets, of the Koh-i-Nur. Prof. Maskelyne says it was accompanied by two other stones in the same mount: so was the Koh-i-nur (see the copies of the original model in the Tower and in several public museums). The character of the mount is somewhat similar to that in the Hon. Miss Eden's sketch of the Koh-i-Nur. This is all that, as it appears to me, can be legitimately deduced from this figure which has been left "to speak for itself."

As to Prof. Maskelyne's own sketch of the Koh-i-Nur, I thank him for it, because I think it may perhaps serve to aid readers who have not seen the original in accepting the hypothesis put forward by me, that it had been mutilated after cutting.

Through the kindness of Mr. L. Fletcher, F.R.S., Keeper of the Minerals in the British Museum, I have recently had an opportunity afforded me of seeing the original plaster model of the Koh-i-Nur, and of comparing it with a glass model similar to the one upon which my remarks as to the mutilation were based, and I find them to be identical in form and all essential details.

Dublin, November 13.

V. BALL.

\section{Pfaff's "Allgemeine Geologie als Exacte Wissenschaft."}

In this work (Leipzig, I873) there is a speculation (on p. I62) that in early geological times the carbonic anhydride, while yet free on the surface of the earth, was sufficient in quantity to exert a pressure of 356 atmospheres. If this had heen the condition of things at any time when the surface temperature was below the critical temperature $\left(30^{\circ} \cdot 9 \mathrm{C}\right.$.), it follows that abundant liquid carbonic anhydride flowed over the surface of the earth, or floated upon the seas; unless it be supposed, which is not probable, that this quantity could be held in solution in the water. Other very important and interesting effects are also involved. The statement of the 356 atmospheres has been quoted without question by so high an authority as Dr. Irving in his "Metamorphism of Rocks."

Pfaff's result, however, is based on a statement of Bischof's (as quoted by Pfaff), that the calcium carbonate of all formations would suffice to cover the surface of the earth to a depth of Iooo fiisse. Pfaff takes 44 per cent. of this to be $\mathrm{CO}_{2}$, and assumes the specific gravity of the rock to be $2 \cdot 6$.

On these data, and taking the fuss as $=0.3$ metre (as stated elsewhere by Pfaff), the $\mathrm{CO}_{2}$ would excrt a pressure, not of 356 atmospheres, but of $33^{*}$, approximately. It appears, in fact, as if Pfaff's result was, through some oversight, calculated as just ten times too great.

Perhaps there is some other explanation of the discrepancy. But, lest it prove an error, I have thought well that attention should be drawn to it, the statement being made on such high authority.

Physical Laboratory, Trinity College, Dublin.

J. JOLY.

NO. 1 I 54 , VOL. 45] 